\title{
Organizational and Legal Features of the Implementation of Cross-border Pipeline Construction Projects in Modern Conditions
}

\author{
Natalia Yaskova ${ }^{1, *}$ and Larisa Zaitseva ${ }^{2}$ \\ ${ }^{1}$ Moscow State University of Civil Engineering,26, Yaroslavskoye shosse, Moscow,129337, Russia \\ ${ }^{2}$ The Institute of State and Law of The Russian Academy of Sciences, 10, Znamenkast., \\ Moscow, 119019, Russia
}

\begin{abstract}
The article raises questions of the implementation of the strategic priorities of development of the national economy. Their relationship and dependence on the successful implementation of transcontinental and cross-border projects are due to the possibility of realization of transit potential of a country, as well as broad prospects of cooperation with neighboring countries in Europe and Asia. The solution of organizational and legal problems of pipelines construction on the territory of countries - participants of such projects as the "Nord Stream", etc., requires a search for the optimal combination of international law and national regulatory procedures. The success of the implementation of cross-border projects is linked by the authors to the development of regulations, as one of the most effective forms of practical implementation of the technology of the interface of economic interests of the countries participants. Being a kind of institutional arrangements, regulations will let to resolve contradictions of international requirements and national procedures promptly.
\end{abstract}

\section{Introduction}

Strategy of Scientific and Technological Development of the Russian Federation [1] has established not only the principles, priorities and measures for implementation of the state policy, but the expected results of their implementation. The general trend of the measures is determined by the need to accelerate the sustainable and balanced development of the Russian Federation for the long term. The Strategy provides for a reorientation of the national economy with raw materials on the innovative model of development. At the same time, the main priorities are becoming:

1. The transition to the development and maintenance of the widespread introduction of digital, intelligent and nano technologies and the development of practical applications of robotic systems.

2. The development of the national economy based on eco-friendly and resource-saving energy, production, processing, methods of transportation and storage of energy focus in a

*Corresponding author: mcua3@yandex.ru 
cost-effective modes.

3. Ensuring of the coherence in the Russian Federation territory on the basis of intelligent transportation and information systems, the creation of international transport and logistics systems.

4. Countermeasure to the threats (man-made, biological, socio-cultural, terrorism and ideological extremism).

5. Changing of approaches and health principles, the transition to environmentally friendly agro- and aquatic household and others.

It should be understood that the implementation of the Strategy for Scientific and Technological Development of the Russian Federation is carried out in a significant contraction of innovation cycles, erosion of disciplinary and sectoral boundaries, changes in the requirements for the competence of employees, as well as the growing of the international standards role.

As a result of extensive discussion of the main directions of scientific and technological development of Russia in the economic forums, sites of international clubs, etc. [2], the harmonization of public research, innovation, industrial, economic and social policies is designed to change not only the quality of intellectual resources of development, but essentially correct formats of international cooperation and integration. The modern paradigm of development not only reduces Russia's participation in international projects, but also assumes a significant expansion of areas of cooperation. To this end, special measures for implementation of strategic facilities are developed, such as: optimization of mechanisms of cooperation with foreign countries; formation and promotion of the actual agenda of cooperation in different spheres; raising the country's participation in international scientific and technical expertise and forecasting; localization of large international projects in Russia; proactive participation of the country in the development of technology standards, and others.

\section{Methods}

Analysis of the system search for the solution of problems of sustainable innovationoriented harmonious development has showed that substantially all of the directions of development are focused on the formation of new and restructuring of traditional exportoriented market segments. The requirement to involve the Russian manufacturers in the global value chain actualizes primarily the need to develop trans-border projects and integrating trends of development of countries within the framework of the Eurasian and European integration. This approach shifts the center of the value added from the production not only in the sphere of design and project finance, but also in the development and adaptation of legal instruments regulating international relations. Therefore it requires a new organizational and legal order, which contributes in cost-effective mode to implementation of a service-oriented approach, where the construction and operation of integration projects with all logically related steps will be implemented in the mode of the agreed with international law enforcement of national procedures of obtaining permits for the construction and its further implementation in accordance with the national law of the states-participants. This will require a structural transformation of each and all manufacturing processes. Similarly, complex, sometimes indiscriminately folding organizational-level links, require restructuring due to the fact that the framework of the traditional partnerships spaces are clearly marked by tendency to expand. A number of components is had to be replaced by more effective, and some to re-create. In any case, the institutional and legal tools of project management must be adapted to the new scale and development goals [3]. They in turn are determined by the parameters of the integration project pool of development. It consists of transcontinental projects of Eurasian integration 
which are characterized by infrastructural mega-projects in the expanded Eurasian format of the "Economic Belt Silk Road", as well as cross-border projects of pipeline construction, such as the "Blue Stream", "South Stream", "Burgas - Alexandria ", etc.

Global integration project of the XXI century, declared in 2015 at the 70th session of the UN General Assembly [4], is the project of "Great Europe", uniting the Eurasian Economic Union, the economic belt of the Silk Road and the European Union. Its implementation is aimed at the Asia-Pacific Region connection with Europe and the Middle East. Thus, the starting phase of the development of the national economy in the conditions of deepening interstate integration requires systematic implementation of the set of infrastructure megaprojects. Their goal is determined by the need to:

1. Provide space relationship of adjacent Eurasian countries as a base for the creation of conditions of coordinated activities of strategic alliances.

2. The vertical integration of corporations and holding companies on the interstate economic level. In this case, the consolidation of production and economic potential of the largest subjects of structural transformations in advanced infrastructure segments will expand not only investment, but communication and innovative potential of all types of post-industrial reproduction processes.

There is no doubt that the realization of these objectives involves the need to ensure a uniform approach in all stages of project implementation. At the core of this approach is the creation of adequate conditions for industrial cooperation in multilateral, regional and global formats, providing reciprocal multilateral resource and commodity flows in an environment with a minimum of administrative barriers. It should be understood that the organizational and legal support of transcontinental infrastructure and cross-border megaprojects with the participation of the Russian Federation shall contribute to: the expansion of trade and investment cooperation, aimed at the intensification of new factors of economic growth; promotion and development of industrial cooperation in the ongoing international projects; cross-border creation of zones of economic, scientific-technical and cultural cooperation; consolidation of transport infrastructure and intermodal transport, to ensure the implementation of the transit potential of Russia; trade and ensure the compatibility of the rules and regulations.

We draw attention to the fact that ensuring of the success of Eurasian transcontinental projects carried out within the framework of existing international organizations, specially created institutions and trust funds, as well as communication platforms, for example, «GGlobal», performing the role of a virtual forum. Interactive mode is supported by discussions on platforms of summits, assemblies, conferences, parliamentary sessions, and others. The scale of the task requires the unification of all formats of developing and implementing special interface technology, implemented in the framework of international law and domestic relations.

We investigate the formation of interface technologies, taking into account the organizational and legal characteristics of the construction of cross-border pipelines, as the example, laying and operation of the pipeline "Nord Stream". The transboundary nature is the main feature of this pipeline. At the same time, the sea route of the gas pipeline is laid through areas of the territorial sea of Denmark, Germany and Russia. Moreover, he goes under the exclusive economic zones of Russia, Finland, Sweden, Denmark, and Germany. The total length of the pipeline is $1,224 \mathrm{~km}$, which $1,189 \mathrm{~km}$ are in the underwater route. Therefore, it is the object of both international law and domestic relations.

International legal practice of the implementation of national procedures for obtaining permits for the installation of "Nord Stream" pipeline is that although the pipeline on the continental shelf of the "resolution" of the coastal State is not required, according to the UN Convention on the Law of the Sea (1982), the consent of the coastal States need to determine the course for the laying of such pipelines (p. 3 of Art. 79) [5]. The legal basis 
for this application of national law is a set of fundamental legal norms. At the same time, we note that the European Union has assigned the project of the pipeline status of "TransEuropean Energy Networks» (Trans-Europen energy Networks - «TEN-E»), as one of the energy projects, "the European Union's top priority", which is "in the interests of the whole of Europe." With regard to the project "North Stream - 2", that he had not received a similar status. This is partly due to the change of the legal regulatory framework for energy projects and the development in 2013 of a special organizational tool such as the Regulation on guidelines for trans-European energy infrastructure [6].

Regulation is aimed, first of all, the rules of the timely development and interoperability of priority corridors and areas of trans-European energy infrastructure. Speeding of the update of the existing energy infrastructure, the redistribution of capacity of new energy infrastructure, energy efficiency, development of new renewable forms of energy, as well as the strengthening of the energy networks constitute the relationships indicated in the Regulations outline as the main target of the project of pipeline construction. A special place among the priority directions of development takes climate protection and the reduction of harmful effects on the environment. In essence, the environmental requirements constitute a basic condition for a decision on the construction.

\section{Results}

The semantic basis of the Rules is determined by the necessity of preventing a number of negative aspects, namely: market fragmentation as a consequence of a lack of communication between the national energy networks; inefficiencies and fail-existing energy infrastructure; high environmental risks associated with the transportation of oil through the use of onshore pipelines and others.

It should be noted that in the Regulation only one type projects is isolated. Other types, even the priority projects and projects of European interest, have no special separate control order. For projects of common interest, provided the relevant requirements, taking into account the priority corridors and areas of energy infrastructure, listed in Annex I to the Regulation [7].

The peculiarity of the Rules adopted is the creation of twelve regional groups whose membership is based on each priority corridor and area, as well as their respective geographical location. Each regional group is given the authority to make its own rules and procedures to meet the requirements. They also have the right to draw up a list of proposed projects of common interest. Based on the regional lists, the European Commission produces a single list of the Union, which is updated every two years. In this design it can be included in the list only once.

The modern context of practical implementation of the project approach was expressed that the Regulations fix certain criteria for projects of common interest. They are divided into general, related to the profitability of the project and its transboundary importance, and for special projects that fall under the category of special energy infrastructure. The latter include: market integration, security, sustainable development, optimal planning of future investments in the network for efficient energy systems projects, reduction of environmental risks for oil transportation projects, etc.

If the project gets the status "of common interest", it is provided with financial and administrative benefits, including a minimization of time losses during the passage of the relevant procedures and the appointment of a European coordinator to assist in dealing with organizational matters. In addition, this project will become a "project of national importance" at the national level. Moreover, a number of these projects include projects that have a negative impact on the environment. In the case of their compliance with the provisions of Directive 92/43/EU of the Council of the $21^{\text {st }}$ of May, 1992 On the 
Conservation of Natural Habitats and of Wild Fauna and Flora and Directive 2000/60/EU of the European Parliament and of the Council of the $23^{\text {rd }}$ of October, 2000 On the Foundations of Community Activity in the field of water policy, they also receive the status of "common interest" [6].

The regulation about the implementation of cross-border projects provide sufficiently detailed account of the project developed by the order, notice periods and report on the completion of certain phases and promotion of the project as a whole, the procedure for issuing permits (including the assessment of the degree of readiness of the project).

\section{Discussion}

The third EU energy package is now also developed [4], it includes a series of directives and regulations, as well as the domestic legislation of certain countries, which are completely transforming the bases and principles of the implementation of energy projects activities. Moreover, it concerns the changes in both the general principles of the functioning of the said sphere (the unity of the power grid, enhancing transparency and strengthening of the protection of consumers' rights), and the introduction of additional restrictions, primarily for vertically integrated companies (VIC) in order to limit their control and monopolization of this sphere. The adoption of the Third Energy Package was the basis for the initiation of the Russian Federation in 2014, a dispute with the EU in the WTO, based on violation of the basic agreements of the organization. It should be noted that the most significant for the Russian Federation is the emergence of potential damage seeps and the introduction of a certification system with regard to foreign operators of transportation systems (i.e. controlled by third countries) in the absence of clear criteria. Furthermore, the request for consultation hold is indicated on the Russian discriminating transport gas control mode in comparison with imported gas. The report of the panel on the case will be prepared not earlier than in May, 2017. Given the rather abstract arguments of the Russian Federation, based on the legitimate expectations of the conflict and the overall focus of the Third Energy Package to ensure competition and the access of more companies on the market, it is extremely difficult to give a clear outlook for the outcome of the dispute.

\section{Conclusion}

Studies of organizational and legal characteristics of the construction of cross-border pipeline have shown that a number of different directions of legal acts partly compensated jointly developed by States agreements, regulations and directives. They implement technology effectively pairing the national interests of the countries - participants. At the same time often fail to balance the interests of States and avoid protracted conflicts and disputes that require additional time and financial resources. In addition, the joint development and adjustment of the current situation on the basis of monitoring requires a much shorter period of time than the adoption of legal acts. This avoids excessive conservatism and overcomes the legal and administrative barriers to the accelerated implementation of cross-border pipeline construction projects.

\section{References}

1. N.Y. Yaskova, Economikastroitelstva, 3(21), 49-59 (2013)

2. 4. Council Directive $92 / 43 / \mathrm{EEC}$ of 21 May 1992 on the conservation of natural habitats and of wild fauna and flora). Access mode: http://eur-lex.europa.eu/eli/dir/1992/43/oj 
3. A.T. Spicyn, Novaya industrializaciya ehkonomiki i perspektivy evrazijskoj integracii, realizacii transkontinental'nyh megaproektov XXI, Prospekt, Moscow (2016)

4. Directive 2000/60/EC of the European Parliament and of the Council of 23 October 2000 establishing a framework for Community action in the field of water policy, Electronic resource, http://data.europa.eu/eli/dir/2000/60/oj

5. N.Y. Yaskova, Nedvizhimost, ehkonomika, upravlenie, 1-2, 52-61 (2014)

6. I.G. Lukmanova, N.Y. Yaskova, Economikastroitelstva, 5, 13 (2014)

7. The third energy package of the EU, Electronic resource, Access mode: http://minenergo.gov.ru/sites/default/files/documents/08/17/154/document-86.doc 